IRA-International Journal of Management \& Social Sciences

ISSN 2455-2267; Vol.05, Issue 02 (2016)

Pg. no. 256-264

Institute of Research Advances

http://research-advances.org/index.php/RAJMSS

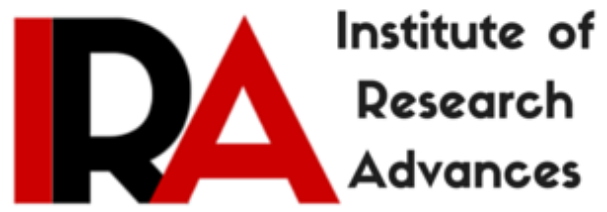

\title{
A Pilot Study for Employability Skills among Students of Management Faculty under NMU, Jalgaon \& SPPU, Pune (with Special Reference to MBA Students)
}

\author{
Hansraj M. Patil ${ }^{1}$ \\ Assistant Professor, Dept. of Computer Mgmt., \\ Systel Institute of Mgmt. and Research, Dhule (M.S) India. \\ Dr. A. N. Patil ${ }^{2}$ \\ Principal, Vasantrao Naik Arts \& Science College, Shahada (M.S.) India.
}

Type of Review: Peer Reviewed.

DOI: http://dx.doi.org/10.21013/jmss.v5.n2.p5

\section{How to cite this paper:}

Patil, H., \& Patil, A. (2016). A Pilot Study for Employability Skills among Students of Management Faculty under NMU, Jalgaon \& SPPU, Pune (with Special Reference to MBA Students). IRA-International Journal of Management \& Social Sciences (ISSN 2455-2267), 5(2), 256-264. doi:http://dx.doi.org/10.21013/jmss.v5.n2.p5

(C) Institute of Research Advances

\section{(cc) EY-NC}

This work is licensed under a Creative Commons Attribution-Non Commercial 4.0 International License subject to proper citation to the publication source of the work.

Disclaimer: The scholarly papers as reviewed and published by the Institute of Research Advances (IRA) are the views and opinions of their respective authors and are not the views or opinions of the IRA. The IRA disclaims of any harm or loss caused due to the published content to any party. 


\begin{abstract}
To remain existing in this world needs ability to survive even Charles Darwin proposes Theory for survival of fittest. To remain fit in today's world is not only the physical abilities but to be engaged in any kind of profession through which one can earn his daily bread and butter. This need appears to be same for each class of society and job. Today this ability can be called as an Employability Skill. It is nothing to do with whether you want a job or want to run any business. For the today's students it is very essential to have these skills not only to bag in new employment opportunities but to retain and to grow on existing one also. Through this research paper authors want to set shoulder to wheel for comparing employability among students of management faculty under two of the leading state universities of Maharashtra i.e. North Maharashtra University, Jalgaon \& Savitribai Phule Pune University with special reference to MBA students. This paper consist concept of employability, factors affecting employability and comparison of employability skills among MBA student under both the universities.
\end{abstract}

Key Words: Employment, Faculty of Management, abilities, skills, career etc.

\title{
1. INTRODUCTION-
}

Along with the changing business scenario, the nature and framework of business also becomes dynamic. The business activities nowadays are getting more and more complex. To handle these complex business activities there is huge demand of multi-skilled intellectuals. Today the jobs in the organizations have taken such shape where they are not task specific. In previous phase of market structure the jobs were more specialized so they needed people with specific job skills. But today, jobs are so enriched and multifaceted. So, on such jobs the individuals having those capabilities are required most. Now organizations give value not to the heads but to the skills, knowledge and abilities in them. All these required skills are called as Employability Skills. These skills are nothing but the individual's ability to gain initial employment, maintain employment, move between roles within the same organisation, obtain new employment if required and (ideally) secure suitable and sufficiently fulfilling work (Hillage\& Pollard, 1998).

The emerging drive of business boosted the employment in all sectors but majorly in services based business. This has increased the demand of management level jobs or those jobs which are based on skills called soft or professional skills. These skills are fundamental or generic as they are required in all kind of jobs. It leads to the need of such competent professionals to provide such services followed by need of such professional courses like Management (MBA and other related courses in Management Faculty). With the typical mindset of studying from a specific university or institute will help candidates to get a good job, aspirants for these courses strive to get admissions in such universities and institutes only. The aspirants with more intellectual capabilities acquired admissions and migrate to such universities like Pune University. Students, who are not able to get admissions there, choose to go elsewhere unwillingly. This causes some sort of differences in the employability scores of students as well among the graduates from different universities.

This paper is an attempt to find out the facts behind whether employability among these students differs as per the university or not? To find out this, authors have conducted pilot study for the students of management faculty (MBA) under North Maharashtra University, Jalgaon and Savitribai Phule Pune University. 


\section{OBJECTIVES OF RESEARCH PAPER-}

By keeping following objectives in mind authors have conducted this study as a pilot study for his Ph. D. research on this topic.

a. To study the level of employability skills among the students of management faculty (MBA) under NMU, Jalgaon \& SPPU, Pune.

b. To understand the factors affecting the level of employability skills of these students.

c. To compare the employability skills among the students of management faculty (MBA) under both the universities.

\section{SIGNIFICANCE OF THE TOPIC-}

New career concepts suggest that employability and career success depend on continuous learning and being adaptable to new job demands or shifts in expertise (Scholarios, 2008). An adequate supply in to the labor market of graduates with viable skills underpins a nation's ability to position itself against global competitors and increase its capacity for innovation and expertise (Toland, 2011). This study will be helpful to provide direction to the efforts of authors of this paper and other such experts or researchers who want to study this concept. Employability is enhanced when students actively engaged in a range of learning activities and when the connection of these activities with employability is made clear to them (The Higher Education Academics, 2006).

\section{EMPPLOYABILITY SKILL COMPONENTS SELECTED BY AUTHORS-}

a. Fundamental/Generic Skills- These skills comprise of Communication Skills, Analytical \& Evaluating Skills and Computer \& Technological Skills etc.

b. Personal Skills- This set deals with the individual's Flexibility \& Adaptability Skills, Work Ethics \& Ability to learn and Stress Coping Skills etc.

c. Teamwork \& Leadership Skills- This set of skills refers to Teamwork \& Participation in work and Leadership Skills of an individual.

\section{RESEARCH PROCESS APLLIED-}

Research Problem- The research problem is to study and compare the level of employability among the students of management faculty (MBA) under NMU, Jalgoan\& SPPU.

Research Design-The Descriptive and Analytical designs are applied for this research paper. Descriptive approach is used because authors want to portray the ground level scenario of the selected topic. On some accounts this study comes to Quantitative approach as well.

Research Hypothesis- The following hypothesis statement led authors to the results of this study-

"There is no difference between the levels of employability skills among the management faculty students (MBA) under NMU, Jalgaon and SPPU,Pune"

Sampling Design- As this is a pilot study, from both the universities authors have decided to select a Sample Size of 100 students in total means 50 from each university. Authors have applied the Simple Random Sampling method for the selection of this sample.

Data Collection Tools- For the collection of primary data related to the employability of the respondents, authors have used Questionnaire designed for this purpose. The questionnaire has been 
designed on the basis of structured questionnaires used in previous researches on similar topics and some modifications are done as per the requirement of this research study. The skill sets discussed earlier in this paper are used for this purpose.

\section{DATA ANALYSIS \& INTERPRETATIONS-}

The data which is collected through questionnaire has been analyzed by the authors as follows. Authors have described the characteristics of the sample first and then the inferential analysis for comparing employability has been carried out. After that the hypothesis has been tested. For the testing of hypothesis authors have used T-test for Independent Samples. Let's have a deep view of analysis further.

\section{Age wise Distribution of a sample-}

Table 1- Age wise distribution of a sample

\begin{tabular}{|c|c|c|c|}
\hline Age into Years & NMU & SPPU & Grand Total \\
\hline 21 & 9 & 5 & 14 \\
\hline 22 & 9 & 10 & 19 \\
\hline 23 & 18 & 23 & 41 \\
\hline 24 & 7 & 9 & 16 \\
\hline 25 & 5 & 3 & 8 \\
\hline 26 & 2 & 0 & 2 \\
\hline Grand Total & $\mathbf{5 0}$ & $\mathbf{5 0}$ & $\mathbf{1 0 0}$ \\
\hline
\end{tabular}

Above table gives the age wise distribution of the sample from both the samples i.e. from NMU \& SPPU. It shows that in total $41 \%$ respondents are of age 23 years while only $2 \%$ are of age 26 years.

II. Gender wise Distribution \& its effect on Employability-

Table 2- Gender wise distribution of sample

\begin{tabular}{|c|c|c|c|}
\hline Gender & NMU & SPPU & Grand Total \\
\hline Female & 25 & 27 & 52 \\
\hline Male & 25 & 23 & 48 \\
\hline Grand Total & $\mathbf{5 0}$ & $\mathbf{5 0}$ & $\mathbf{1 0 0}$ \\
\hline
\end{tabular}

Above table shows that the sample has equally distributed by gender that means almost equal male and female respondents have filled up questionnaires.

Effect of Gender on Employability-

Table 3-Effect of gender on employability

\begin{tabular}{|l|c|c|c|c|c|c|c|r|}
\hline $\begin{array}{c}\text { Row } \\
\text { Labels }\end{array}$ & $\begin{array}{c}\text { Mean } \\
\text { Comm } \\
\text { Skills }\end{array}$ & $\begin{array}{c}\text { Mean } \\
\text { Ana. } \\
\text { Skills }\end{array}$ & $\begin{array}{c}\text { Mean } \\
\text { Comp } \\
\text { \& Tech } \\
\text { Skills }\end{array}$ & $\begin{array}{c}\text { Mean } \\
\text { Flexi \& } \\
\text { Adapt } \\
\text { Skills }\end{array}$ & $\begin{array}{c}\text { Mean } \\
\text { W.Ethi } \\
\text { \& } \\
\text { Ability } \\
\text { Learn }\end{array}$ & $\begin{array}{c}\text { Mean } \\
\text { Stress } \\
\text { Coping } \\
\text { Skills }\end{array}$ & $\begin{array}{c}\text { Mean } \\
\text { Leader } \\
\text { ship } \\
\text { Skills }\end{array}$ & $\begin{array}{c}\text { Mean } \\
\text { Teamwork } \\
\text { \&Particpn }\end{array}$ \\
\hline Female & 19.19 & 17.81 & 19.37 & 19.65 & 19.46 & 17.42 & 19.73 & 20.56 \\
\hline Male & 18.06 & 17.60 & 19.15 & 19.02 & 18.88 & 17.40 & 18.98 & 20.04 \\
\hline G.Total & $\mathbf{1 8 . 6 5}$ & $\mathbf{1 7 . 7 1}$ & $\mathbf{1 9 . 2 6}$ & $\mathbf{1 9 . 3 5}$ & $\mathbf{1 9 . 1 8}$ & $\mathbf{1 7 . 4 1}$ & $\mathbf{1 9 . 3 7}$ & $\mathbf{2 0 . 3 1}$ \\
\hline
\end{tabular}


Above table shows that the employability of female respondent is observed more for each of the given skill sets.

\section{Basic Graduation wise Distribution \& its effect on Employability-}

Table 4- Basic Graduation wise distribution of sample

\begin{tabular}{|l|c|c|c|}
\hline \multicolumn{1}{|c|}{ Basic Graduation } & NMU & SPPU & Grand Total \\
\hline Arts & 2 & 1 & 3 \\
\hline Commerce \& Mgt. & 42 & 48 & 90 \\
\hline Science \& Technology & 6 & 1 & 7 \\
\hline Grand Total & $\mathbf{5 0}$ & $\mathbf{5 0}$ & $\mathbf{1 0 0}$ \\
\hline
\end{tabular}

Above table shows that $90 \%$ respondents following MBA course are from Commerce \& Management background and few of them are from Arts and Science background.

Effect of Basic Graduation on Employability-

Table 5 -Effect of Basic Graduation wise distribution on Employability

\begin{tabular}{|l|c|c|c|c|c|c|c|c|}
\hline \multicolumn{1}{|c|}{ Row Labels } & $\begin{array}{c}\text { Mean } \\
\text { Comm } \\
\text { Skills }\end{array}$ & $\begin{array}{c}\text { Mean } \\
\text { Ana. } \\
\text { Skills }\end{array}$ & $\begin{array}{c}\text { Mean } \\
\text { Comp } \\
\text { \& Tech } \\
\text { Skills }\end{array}$ & $\begin{array}{c}\text { Mean } \\
\text { Flexi \& } \\
\text { Adapt } \\
\text { Skills }\end{array}$ & $\begin{array}{c}\text { Mean W. } \\
\text { Ethi \& } \\
\text { Ability } \\
\text { Learn }\end{array}$ & $\begin{array}{c}\text { Mean } \\
\text { Stress } \\
\text { Coping } \\
\text { Skills }\end{array}$ & $\begin{array}{c}\text { Mean } \\
\text { Leadership } \\
\text { Skills }\end{array}$ & $\begin{array}{c}\text { Mean } \\
\text { Teamwork } \\
\text { \& } \\
\text { Particpn }\end{array}$ \\
\hline Arts & 20.33 & 22.00 & 21.33 & 21.33 & 19.67 & 17.67 & 20.33 & 19.67 \\
\hline Commerce \& Mgt. & 18.43 & 17.47 & 19.14 & 19.29 & 19.19 & 17.34 & 19.21 & 20.27 \\
\hline Science \& Techno. & 20.71 & 19.00 & 19.86 & 19.29 & 18.86 & 18.14 & 21.00 & 21.14 \\
\hline Grand Total & $\mathbf{1 8 . 6 5}$ & $\mathbf{1 7 . 7 1}$ & $\mathbf{1 9 . 2 6}$ & $\mathbf{1 9 . 3 5}$ & $\mathbf{1 9 . 1 8}$ & $\mathbf{1 7 . 4 1}$ & $\mathbf{1 9 . 3 7}$ & $\mathbf{2 0 . 3 1}$ \\
& & & & & & & & \\
\hline
\end{tabular}

From the above table it can be said that the respondents with Arts and Science background scored more than those with Commerce \& Management background. 
IV. Specialization of the respondents for MBA Course-

Table 6- Specialization wise distribution of sample

\begin{tabular}{|l|c|c|c|}
\hline \multicolumn{1}{|c|}{ Specialization } & NMU & SPPU & Grand Total \\
\hline Computer Mgt. & 0 & 1 & 1 \\
\hline Finance & 21 & 9 & 30 \\
\hline HR & 5 & 25 & 30 \\
\hline IT & 0 & 1 & 1 \\
\hline Marketing & 24 & 14 & 38 \\
\hline Grand Total & $\mathbf{5 0}$ & $\mathbf{5 0}$ & $\mathbf{1 0 0}$ \\
\hline
\end{tabular}

Above table shows that respondents from NMU have selected Finance (42\%) and Marketing (48\%) specialization majorly while respondents from SPPU have selected HR (50\%) and Marketing (28\%) majorly.

V. Family Income wise Distribution \& its effect on Employability-

Table 7-Family Income wise distribution of sample

\begin{tabular}{|l|l|l|l|}
\hline Family Income in Rs. & NMU & SPPU & Grand Total \\
\hline 3 lakh \& Above & 7 & 8 & 15 \\
\hline 1-3 lakh & 11 & 13 & 24 \\
\hline Up to 1 lakh & 32 & 29 & 61 \\
\hline Grand Total & $\mathbf{5 0}$ & $\mathbf{5 0}$ & $\mathbf{1 0 0}$ \\
\hline
\end{tabular}

Above table shows that most of the respondents from both samples have family income up to 1 lakh (61\%) followed by 1-3 lakh (24\%) and lastly above 3lakh (15\%).

Effect of Family Income on Employability-

Table 8-Effect of Family Income on Employability

\begin{tabular}{|c|c|c|c|c|c|c|c|c|}
\hline Row Labels & $\begin{array}{c}\text { Mea } \\
\text { n } \\
\text { Com } \\
\text { m } \\
\text { Skill } \\
\text { S }\end{array}$ & $\begin{array}{l}\text { Mea } \\
\text { n } \\
\text { Ana. } \\
\text { Skill } \\
\text { s }\end{array}$ & $\begin{array}{c}\text { Mean } \\
\text { Comp } \\
\& \\
\text { Tech } \\
\text { Skills }\end{array}$ & $\begin{array}{l}\text { Mean } \\
\text { Flexi } \\
\text { \& } \\
\text { Adapt } \\
\text { Skills }\end{array}$ & $\begin{array}{c}\text { Mean } \\
\text { W.Ethi } \\
\text { \& } \\
\text { Ability } \\
\text { Learn }\end{array}$ & $\begin{array}{l}\text { Mean } \\
\text { Stress } \\
\text { Copin } \\
\text { g } \\
\text { Skills }\end{array}$ & $\begin{array}{c}\text { Mean } \\
\text { Leader } \\
\text { ship } \\
\text { Skills }\end{array}$ & $\begin{array}{c}\text { Mean } \\
\text { Teamwo } \\
\text { rk } \\
\text { \&Partici } \\
\text { pant }\end{array}$ \\
\hline Up to 1 lakh & 18.25 & 17.90 & 18.74 & 19.48 & 19.15 & 17.61 & 19.23 & 19.97 \\
\hline 1-3 lakh & 18.75 & 17.38 & 20.04 & 18.79 & 19.00 & 16.42 & 19.38 & 20.46 \\
\hline 3 lakh \& Above & 20.13 & 17.47 & 20.13 & 19.73 & 19.60 & 18.20 & 19.93 & 21.47 \\
\hline Grand Total & 18.65 & 17.71 & 19.26 & 19.35 & 19.18 & 17.41 & 19.37 & 20.31 \\
\hline
\end{tabular}


Above table reflects that respondents who belong to income group of up to 1 lakh and income group of above 3 lakh have scored more in employability of majority of skill sets.

VI. University wise comparison of Employability of Respondents-

Table 9-Effect of Family Income on Employability

\begin{tabular}{|c|c|c|c|c|c|c|c|c|}
\hline Row Labels & $\begin{array}{c}\text { Mean } \\
\text { Comm } \\
\text { Skills }\end{array}$ & $\begin{array}{c}\text { Mean } \\
\text { Ana. } \\
\text { Skills }\end{array}$ & $\begin{array}{c}\text { Mean } \\
\text { Comp } \\
\begin{array}{c}\text { Tech } \\
\text { Tech } \\
\text { Skills }\end{array}\end{array}$ & $\begin{array}{c}\text { Mean } \\
\text { Flexi } \\
\mathbf{\&} \\
\text { Adapt } \\
\text { Skills }\end{array}$ & $\begin{array}{c}\text { Mean } \\
\text { W.Ethi } \\
\mathbf{\&} \\
\text { Ability } \\
\text { Learn }\end{array}$ & $\begin{array}{c}\text { Mean } \\
\text { Stress } \\
\text { Coping } \\
\text { Skills }\end{array}$ & $\begin{array}{c}\text { Mean } \\
\text { Leaders } \\
\text { hip } \\
\text { Skills }\end{array}$ & $\begin{array}{c}\text { Mean } \\
\text { Teamwo } \\
\text { rk } \\
\text { \&Partici } \\
\text { pant }\end{array}$ \\
\hline NMU & 18.50 & 17.58 & 19.50 & 19.30 & 19.16 & 17.50 & 19.38 & 20.28 \\
\hline SPPU & 18.80 & 17.84 & 19.02 & 19.40 & 19.20 & 17.32 & 19.36 & 20.34 \\
\hline Grand Total & $\mathbf{1 8 . 6 5}$ & $\mathbf{1 7 . 7 1}$ & $\mathbf{1 9 . 2 6}$ & $\mathbf{1 9 . 3 5}$ & $\mathbf{1 9 . 1 8}$ & $\mathbf{1 7 . 4 1}$ & $\mathbf{1 9 . 3 7}$ & $\mathbf{2 0 . 3 1}$ \\
\hline
\end{tabular}

Above table shows there is negligible difference between employability of respondents from both the universities.

\section{Hypothesis Testing-}

The hypothesis gives direction to the research. For this research paper the hypothesis statement is as follows-

"There is no difference between the levels of employability skills among the management faculty students (MBA) under NMU, Jalgaon and SPPU,Pune"

\section{Testing of Hypothesis-}

Hypothesis is to be tested statistically. This validates the research more. Here there are several variables in this research. Two independent samples are present here i.e. sample from NMU \& SPPU. To test the variances of the variables from these two independent samples it becomes necessary to test such hypothesis by T-test of Independent Samples. Following table shows the testing and its result come out of software available for research tools.

Table 10-t-Test for Independent Sample

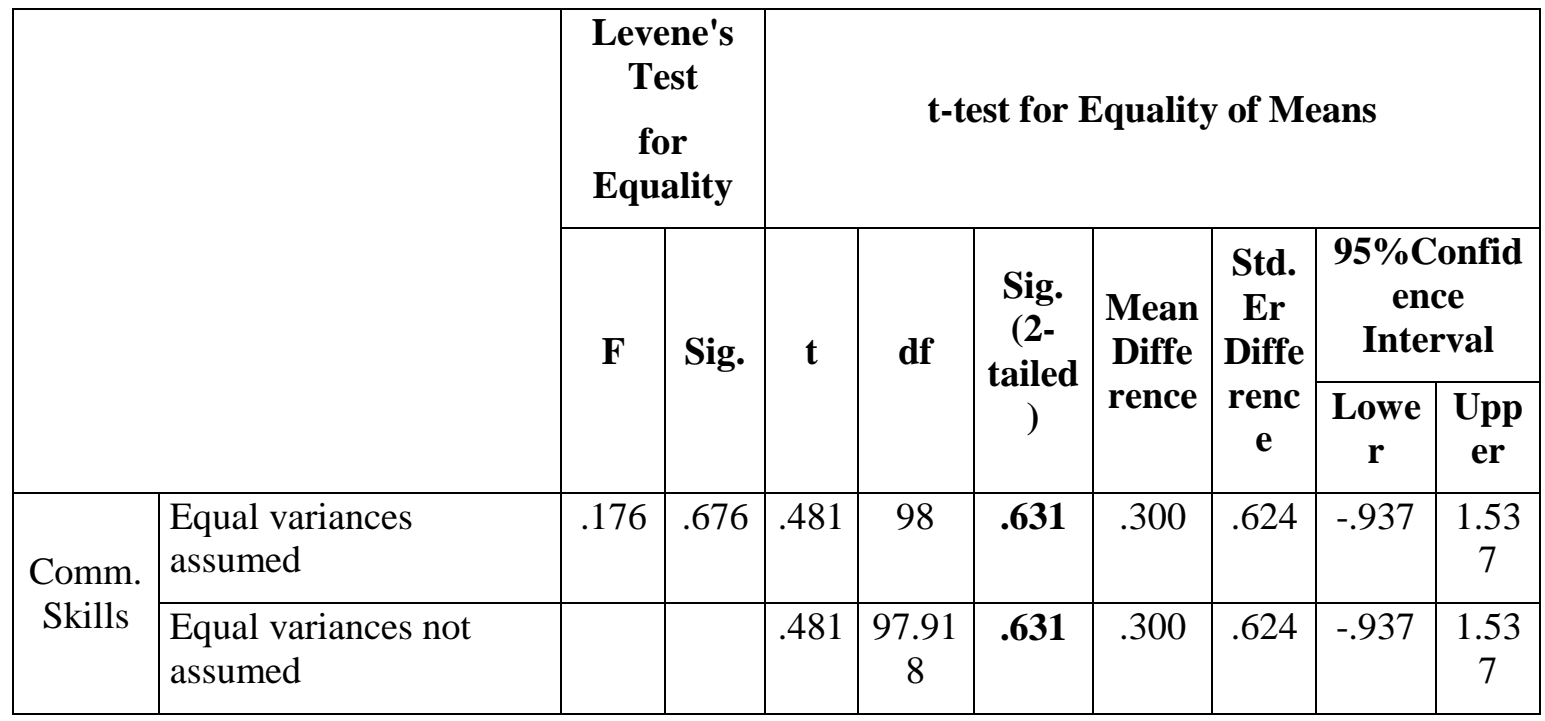




\begin{tabular}{|c|c|c|c|c|c|c|c|c|c|c|}
\hline \multirow{2}{*}{$\begin{array}{l}\text { Analyt } \\
\text { Skills }\end{array}$} & $\begin{array}{l}\text { Equal variances } \\
\text { assumed }\end{array}$ & 607 & .438 & .448 & 98 & .655 & .260 & .581 & -.893 & $\begin{array}{c}1.41 \\
3\end{array}$ \\
\hline & $\begin{array}{l}\text { Equal variances not } \\
\text { assumed }\end{array}$ & & & .448 & $\begin{array}{c}95.79 \\
5\end{array}$ & .655 & .260 & .581 & -.893 & $\begin{array}{c}1.41 \\
3\end{array}$ \\
\hline \multirow{2}{*}{$\begin{array}{l}\text { Comp } \\
\text { \& Tech }\end{array}$} & $\begin{array}{l}\text { Equal variances } \\
\text { assumed }\end{array}$ & .006 & .937 & $\begin{array}{c}- \\
.613\end{array}$ & 98 & .541 & -.480 & .783 & $\begin{array}{c}- \\
2.034\end{array}$ & $\begin{array}{c}1.07 \\
4\end{array}$ \\
\hline & $\begin{array}{l}\text { Equal variances not } \\
\text { assumed }\end{array}$ & & & $\begin{array}{c}- \\
.613\end{array}$ & $\begin{array}{c}96.85 \\
1\end{array}$ & .541 & -.480 & .783 & $\begin{array}{c}- \\
2.034\end{array}$ & $\begin{array}{c}1.07 \\
4\end{array}$ \\
\hline \multirow{2}{*}{$\begin{array}{c}\text { Flex } \\
\text { \&Adpt. }\end{array}$} & $\begin{array}{l}\text { Equal variances } \\
\text { assumed }\end{array}$ & $\begin{array}{c}1.15 \\
2\end{array}$ & .286 & .165 & 98 & .869 & .100 & .607 & $\begin{array}{c}- \\
1.104\end{array}$ & $\begin{array}{c}1.30 \\
4\end{array}$ \\
\hline & $\begin{array}{l}\text { Equal variances not } \\
\text { assumed }\end{array}$ & & & .165 & $\begin{array}{c}96.14 \\
1\end{array}$ & .869 & .100 & .607 & $\begin{array}{c}- \\
1.105\end{array}$ & $\begin{array}{c}1.30 \\
5\end{array}$ \\
\hline \multirow{2}{*}{$\begin{array}{l}\text { Work } \\
\text { Ethics }\end{array}$} & $\begin{array}{l}\text { Equal variances } \\
\text { assumed }\end{array}$ & $\begin{array}{c}2.56 \\
1\end{array}$ & .113 & .060 & 98 & .953 & .040 & .671 & $\begin{array}{c}- \\
1.291\end{array}$ & $\begin{array}{c}1.37 \\
1\end{array}$ \\
\hline & $\begin{array}{l}\text { Equal variances not } \\
\text { assumed }\end{array}$ & & & .060 & $\begin{array}{c}97.55 \\
2\end{array}$ & .953 & .040 & .671 & $\begin{array}{c}- \\
1.291\end{array}$ & $\begin{array}{c}1.37 \\
1\end{array}$ \\
\hline \multirow{2}{*}{$\begin{array}{l}\text { Stress } \\
\text { coping }\end{array}$} & $\begin{array}{l}\text { Equal variances } \\
\text { assumed }\end{array}$ & .374 & .542 & $\begin{array}{c}- \\
.294\end{array}$ & 98 & .770 & -.180 & .613 & $\begin{array}{c}- \\
1.396\end{array}$ & $\begin{array}{c}1.03 \\
6\end{array}$ \\
\hline & $\begin{array}{l}\text { Equal variances not } \\
\text { assumed }\end{array}$ & & & $\begin{array}{c}- \\
.294\end{array}$ & $\begin{array}{c}97.98 \\
9\end{array}$ & .770 & -.180 & .613 & $\begin{array}{c}- \\
1.396\end{array}$ & $\begin{array}{c}1.03 \\
6\end{array}$ \\
\hline \multirow{2}{*}{$\begin{array}{l}\text { Leaders } \\
\text { hip } \\
\text { Skills }\end{array}$} & $\begin{array}{l}\text { Equal variances } \\
\text { assumed }\end{array}$ & .179 & .673 & $\begin{array}{c}- \\
.032\end{array}$ & 98 & .974 & -.020 & .616 & $\overline{-}$ & $\begin{array}{c}1.20 \\
2\end{array}$ \\
\hline & $\begin{array}{l}\text { Equal variances not } \\
\text { assumed }\end{array}$ & & & $\begin{array}{c}- \\
.032\end{array}$ & $\begin{array}{c}97.97 \\
7\end{array}$ & .974 & -.020 & .616 & $\overline{-}$ & $\begin{array}{c}1.20 \\
2\end{array}$ \\
\hline \multirow{2}{*}{$\begin{array}{c}\text { Team } \\
\text { \&Partic } \\
\text { ipant }\end{array}$} & $\begin{array}{l}\text { Equal variances } \\
\text { assumed }\end{array}$ & $\begin{array}{c}4.38 \\
0\end{array}$ & .039 & .092 & 98 & .927 & .060 & .651 & $\begin{array}{c}- \\
1.233\end{array}$ & $\begin{array}{c}1.35 \\
3\end{array}$ \\
\hline & $\begin{array}{l}\text { Equal variances not } \\
\text { assumed }\end{array}$ & & & .092 & $\begin{array}{c}93.68 \\
2\end{array}$ & .927 & .060 & .651 & $\begin{array}{c}- \\
1.233\end{array}$ & $\begin{array}{c}1.35 \\
3\end{array}$ \\
\hline
\end{tabular}

If we observe the above table carefully we can get that the value in the column Sig. (2-Tailed) all the values are greater than $0.05(>0.05)$ which is standard value of ' $t$ ' for $95 \%$ confidence interval. Due to which we have to accept the hypothesis mentioned above which means there is no such significant difference in the employability skills among students of management faculty studying under NMU, Jalgaon and SPPU. The statistical quantitative analysis shown in table-9 also supports the outcome of hypothesis testing.

\section{CONCLUSION-}

Through this research paper authors have studied the level of employability skills among the management faculty students (MBA) from NMU, Jalgoan and SPPU. The difference of employability has been observed between the students from both of these universities. As the purpose of this research paper is to study and compare the level of employability that has been achieved through this attempt. As this study is a pilot study, authors can study this concept at broader level for Ph.D. research which widens the scope of this research. 


\section{REFERENCES-}

1. Bajpai, N., Business Research Methods, Pearson-Dorling Kindersley (India), 2011, (p. 5).

2. DivyaShukla, Employability Skill among Professionals - Chagrin of HR Executives in Indian Labor Market : A Study on Engineering Graduates of Bhopal City . VSRD International Journal of Business \&Mngt. Research Vol. 2 (8), 2012.

3. Hillage, J. and Pollard, E., Employability: developing a framework for policy analysis. Research Brief 85, Department for Education and Employment, London, 1998.

4. Kothari, C., R., Research Methodology-Methods \& Techniques, New Age International Publishers, 2011.

5. McGrath S., What is employability?, Retrieved from www.nottingham.ac.uk/shared_uccer/epa_docs/what_is_employability.pdf, unknown

6. Sachdeva, J., K., Business Research Methodology, Himalaya Publications, 2010.

7. The Higher Education Academic, Pedagogy for employability, 2006, Retrieved from http://www.heacademy.ac.uk/resources/detail/employability/employability497

8. Toland A., HE STEM Employability Skills Review-The National HE STEM Program, University of Birmingham, 2011.

9. Yorke M., Knight P., Embedding employability into the curriculum. York, Higher Education Academy, 2006. 